\title{
CULTIVATION OF SUSPENDED CELL CULTURES AND BIOFILM OF ACIDITHIOBACILLUS FERROOXIDANS JCM 3863 IN PRESENCE OF COPPER IONS AND HIGH CONCENTRATIONS OF FERROUS IONS
}

\author{
Kristina Lazarova, Vyara Mamatarkova
}

\begin{abstract}
Bacteria Acidithiobacillus ferrooxidans are implemented usually in many biotechnological processes as bioleaching of metals from low grade ores and in some processes with ecological importance as purification of waste waters and gases, removal of metals from solid wastes.

Suspended cultures and biofilm of Acidithiobacillus ferrooxidans JCM 3863 were cultivated in two media - with 15 and $18 \mathrm{~g} / \mathrm{l}$ initial concentration of iron ions. Biofilm and suspended cultures have been cultivated in five consecutive cycles in each nutrient medium in presence of $5 \mathrm{~g} / 1$ copper ions to complete oxidation of ferrous to ferric ions. In the end the biofilm thickness has been determined.

Mean rates of oxidation were compared for each cycle of cultivation. In consecutive cultivation of suspended cells and biofilm in medium $15 \mathrm{~K}$ after addition of copper ions the mean rates decrease in first three cycles, after that they increase in cycles 4 and 5 . In consecutive cultivation of suspended cells in medium $18 \mathrm{~K}$ the mean rates are different for all cycles. In biofilm in medium $18 \mathrm{~K}$ after addition of copper ions there is decrease of mean rates compared to the first cycle, but they stay constant in the next cycles. Comparison of mean rates of ferrous ions oxidation shows that in biofilm they are higher than in suspended cultures.

From results of presented research we can make the conclusion that the biofilm is better than suspended cells for industrial biotechnological processes in presence of copper ions and high concentrations of ferrous ions.
\end{abstract}

Keywords: Acidithiobacillus ferrooxidans, biofilm, copper ions, high concentration of ferrous ions

\section{INTRODUCTION}

Modern society is impossible without information technology. But they generate a large amount of solid waste that are dangerous source of pollution. At the same time they represent a valuable secondary raw material for the production of plastics and metals. Recycling of electronic waste is an important activity not only in terms of their treatment as waste, but also to extract valuable components and energy savings $[1,2]$. Biotechnological methods for extracting metals from secondary sources of raw materials does not require the incorporation of large amounts of energy to ensure the high temperatures and generate relatively small amounts of waste which are non-toxic [3]. Mainly involved in these processes is genus Acidithiobacillus - species Acidithiobacillus ferrooxidans and Acidithiobacillus thiooxidans [4, 5]. Research conducted by Acidithiobacillus ferrooxidans JSM 3863 demonstrates their possible application for leaching of copper from printed circuit boards [6], copper and PMG (platinum and palladium) from automobile exhaust converters [7, $8]$ and hight resistance to presence of toxic metal ions as nickel, cobalt [9] and silver [10]. Bioleaching rate depends upon the concentration of ferric ions in the solution therefore of practical interest are studies related to the behavior of Acidithiobacillus ferrooxidans at higher initial concentrations of iron, and the possibility of their adaptation to them. It has been found that the biofilm of these bacteria are more resistant to high concentrations of ferric and ferrous ions $[11,12]$, as well as other environmental factors [13]. It is necessary to investigate bacterial oxidation in presence of copper ions and elevated concentrations of iron.

The aim of this work is to investigate in high innitial concentration of ferrous ions the bacterial oxidation in submerged cultures and biofilm of Acidithiobacillus ferrooxidans JCM 3863 in presence of copper ions.

\section{MATERIALS AND METHODS}

Microorganisms. The experiments were carried out with the strain Acidithiobacillus ferrooxidans JCM 3863 from Japan Collection of Microorganisms.

Medium. Bacteria were cultivated in liquid media [14] with addition of different amount of ferrous ions from initial concentrations 15 and $18 \mathrm{~g} / \mathrm{l}$ - respectively, (15K and $18 \mathrm{~K}$ ) liquid media. Biofilm was cultivated in the same media after its formation on carriers polyethylene cylinders, in fed-batch $[15,16]$. In each medium copper ions in concentration $5 \mathrm{~g} / \mathrm{l}$ were added.

Analytical methods. Concentrations of ferrous, ferric ions and total iron were determined spectrophotometrically [17].

Determination of biofilm thickness. Thickness of biofilm was determined on the base of dried weight, density and area of the carriers $[13,15,16]$.

Experimental conditions. Acidithiobacillus ferrooxidans JCM 3863 were cultivated in shake 
flasks in batch at $190 \mathrm{rpm}$ and $28 \pm 0.5^{\circ} \mathrm{C}$. Suspended cells were cultivated in $100 \mathrm{ml}$ liquid medium $15 \mathrm{~K}$ or $18 \mathrm{~K}$ (inoculum $1 \%$ ). Biofilm was cultivated in $250 \mathrm{ml}$ liquid media $15 \mathrm{~K}$ or $18 \mathrm{~K}, 4$ carriers with formed biofilm in each flack. As biological controls are used the results obtained by cultivation of Acidithiobacillus ferrooxidans JCM 3863 in discribed media without copper ions - for suspended cell cultures it is named "biological control", for biofilm - "cycle 0".

\section{RESULTS AND DISCUSSION}

Cultivation of suspended cell cultures in liquid medium $15 K$

Dynamics of the process of ferric ions production in liquid medium $15 \mathrm{~K}$ with suspended cells cultures are presented on Fig. 1. It can be seen the similarities and differences in the dynamic of the process in submerged cultures. The results show that the dynamic is slower in the first cycle and then in cycles 2, 4 and 5 it is similar and faster. For the biological control the process is shorte - complete oxidation of ferrous ions is reached after 48 hours. In all cycles of cultivation expressed lag-phase is missing clearly. Acceleration of the dynamics in the last two cycles could be considered as adaptation of the culture to initial concentration of ferrous ions $15 \mathrm{~g} / 1$ and to presence of copper ions.

Mean rates of ferrous ions oxidation and ferric ions production were compared for each cycle of cultivation. In consecutive cultivation of suspended cells in medium $15 \mathrm{~K}$ after addition of copper ions the mean rates decrease in first three cycles after that they increase in cycles 4 and 5 - Fig. 2.

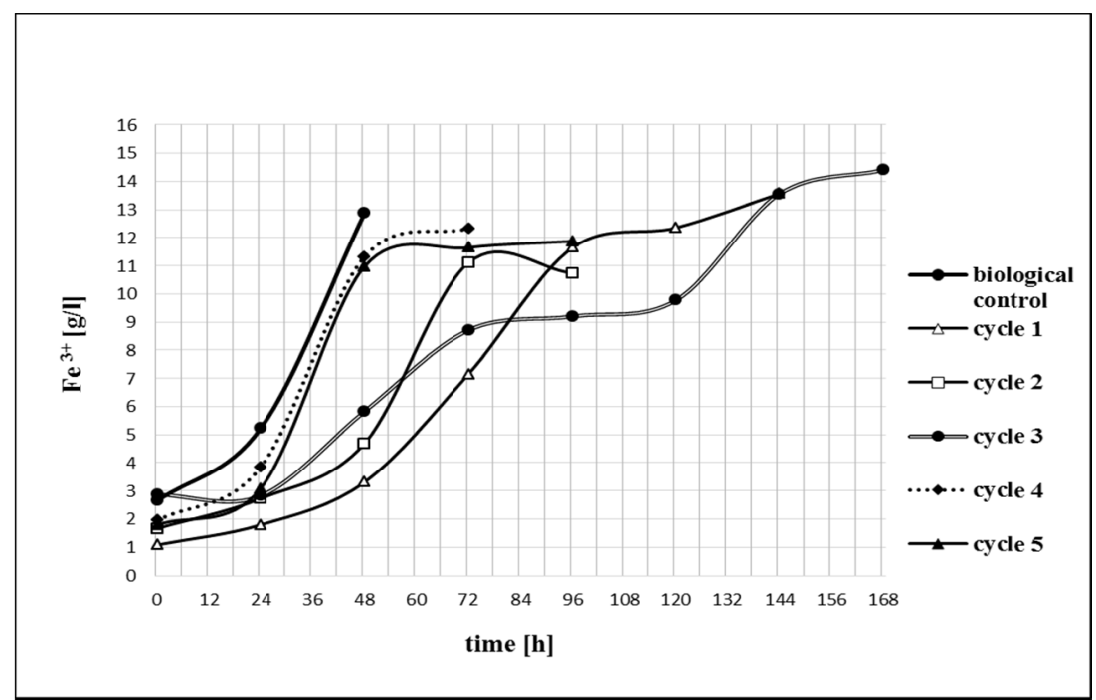

Fig. 1. Dynamics of ferric ions production in suspended cultures - biological control in $15 \mathrm{~K}$ medium and five cycles in $15 \mathrm{~K}$ medium with $5 \mathrm{~g} / \mathrm{Cu}^{2+}$.

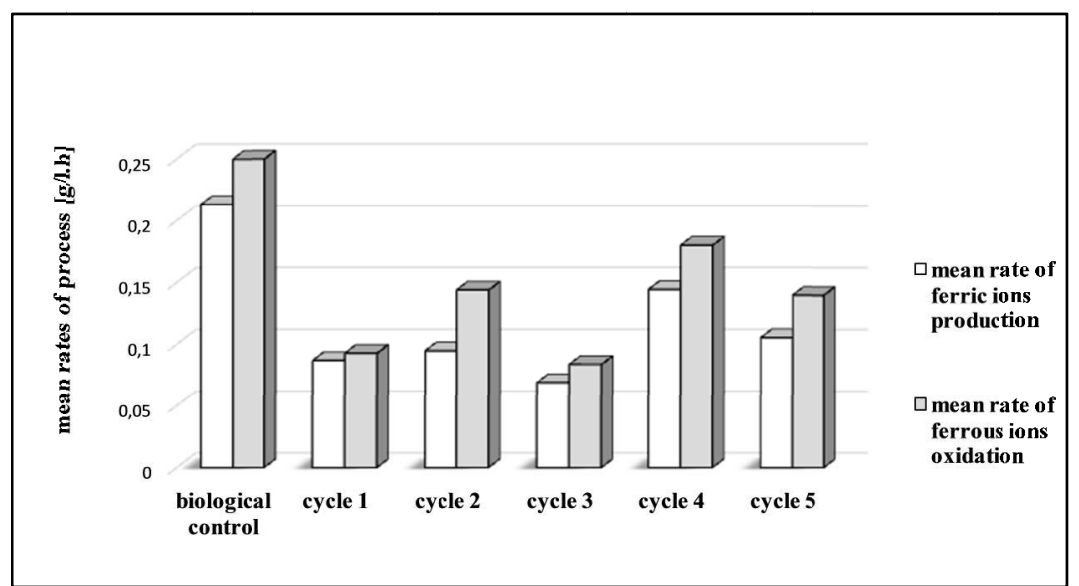

Fig. 2. Mean rates of ferric ions production in suspended cells cultures - biological control in $15 \mathrm{~K}$ medium and five cycles in $15 \mathrm{~K}$ medium with $5 \mathrm{~g} / \mathrm{C} \mathrm{Cu}^{2+}$. 
If the mean rates are compared in the five cycles of cultivation with the biological control they are different, which can be seen on Fig. 2. The statistical analysis (ANOVA Single factor) shown that they are the same in the first three cycles. After the decrease of the rates it is observed increasing in cycles 4 and 5 which are statistically same. These results and the accelerated dynamics can be explained with adaptation of the culture. The slight differences between rates of ferrous ions oxidation and ferric ions production are caused by sedimentation of ferric ions as jarosite on the bottom and sides of flacks. This type of sedimentation is always observed in cultivation of Acidithiobacillus ferrooxidans in media with ferrous ions $[18,19]$.

\section{Cultivation of suspended cells cultures in liquid} medium $18 K$

From analyse of the dynamics of cultivation of suspended cells cultures in liquid medium $18 \mathrm{~K}$ it can be seen that after addition of copper ions the process of oxidation is going on similar dynamic except cycle 3. This result shows that the activity of microorganisms is preserved - exhaustion of the culture or inhibition of the culture to initial concentration of ferrous ions $18 \mathrm{~g} / 1$ and presence of copper ions does not occur. Increase of activity in the five consecutive cycles is not observed. It has to be noted that there is presence of sedimentation of ferrous ions as jarosite like cultivation of cultures in $15 \mathrm{~K}$ medium. For each cycle of cultivation are determined mean rates of ferrous ions oxidation and ferric ions production. The results are shown on Fig. 4.

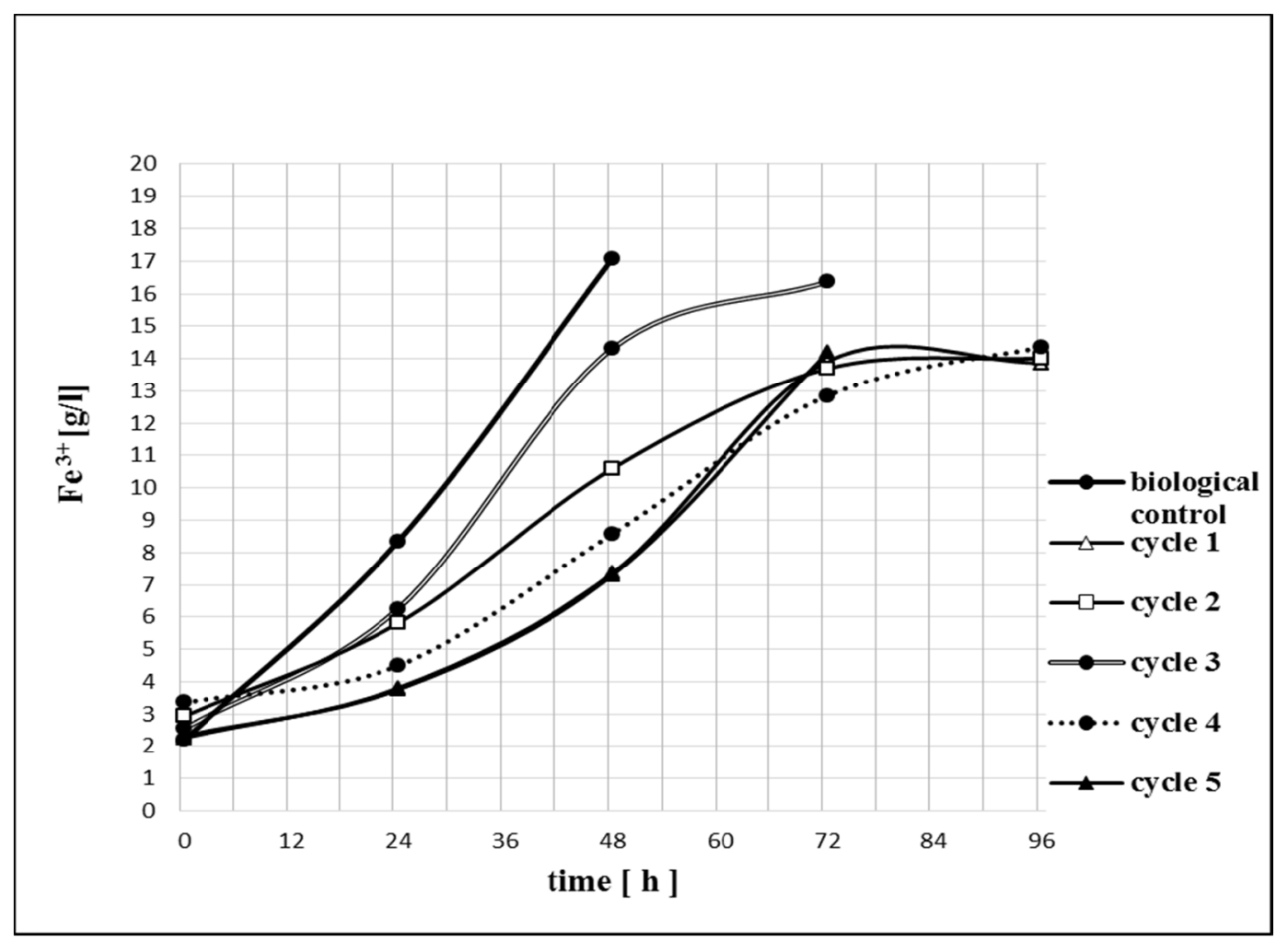

Fig. 3. Dynamics of ferric ions production in suspended cultures - biological control in $18 \mathrm{~K}$ medium and five cycles in $18 \mathrm{~K}$ medium with $5 \mathrm{~g} / \mathrm{C} \mathrm{Cu}^{2+}$.

It can be seen that compared to the biological control the mean rates in the five consecutive cycles are lower. Statistical analysis (ANOVA Single factor) confirms this statement. It is of practical interest to check whether the five cycles have statistically the same mean rates. The sequential statistical analysis of mean rates has shown that they differ from each other. For this reason, it can not be said that there is an effect of adaptation. It is important to note, that there is no permanent decrease in activity during the five consecutive cycles of cultivation. 


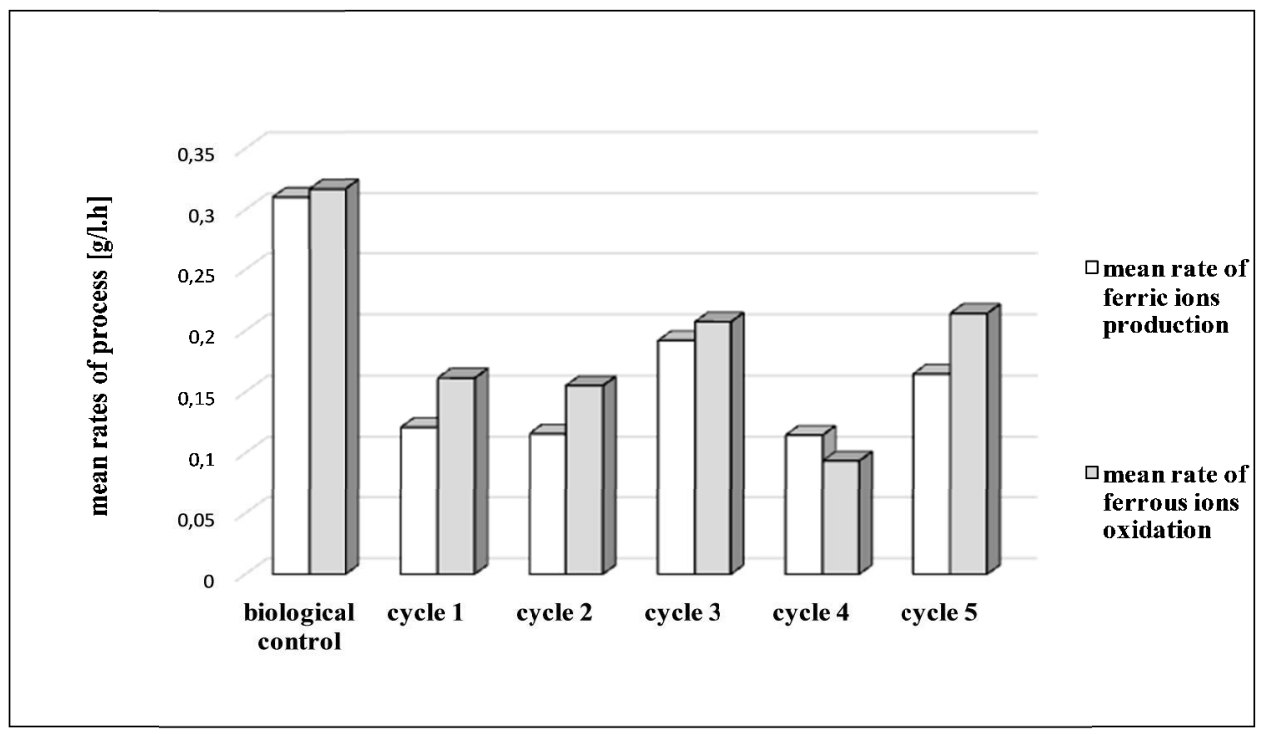

Fig. 4. Mean rates of ferric ions production in suspended cells cultures - biological control in $18 \mathrm{~K}$ medium and five cycles in $18 \mathrm{~K}$ medium with $5 \mathrm{~g} / 1 \mathrm{Cu}^{2+}$.

\section{Cultivation of biofilm in liquid medium $15 \mathrm{~K}$}

The comparison between process dynamics over the seven cycles of biofilm cultivation in culture medium $15 \mathrm{~K}$ in the presence of $5 \mathrm{~g} / 1$ copper ions is presented on Fig. 5. Full oxidation of the ferrous ions is reached for $48-72$ hours. It is clear to see that when the copper ions are added through cycle 1 , biofilm activity decreases, then it adapts to their presence, and with the exception of cycle 3, the process takes 48 hours.

For each cycle of cultivation mean rates of ferrous ions oxidation and ferric ions production were calculated. The results are shown on Fig. 6.

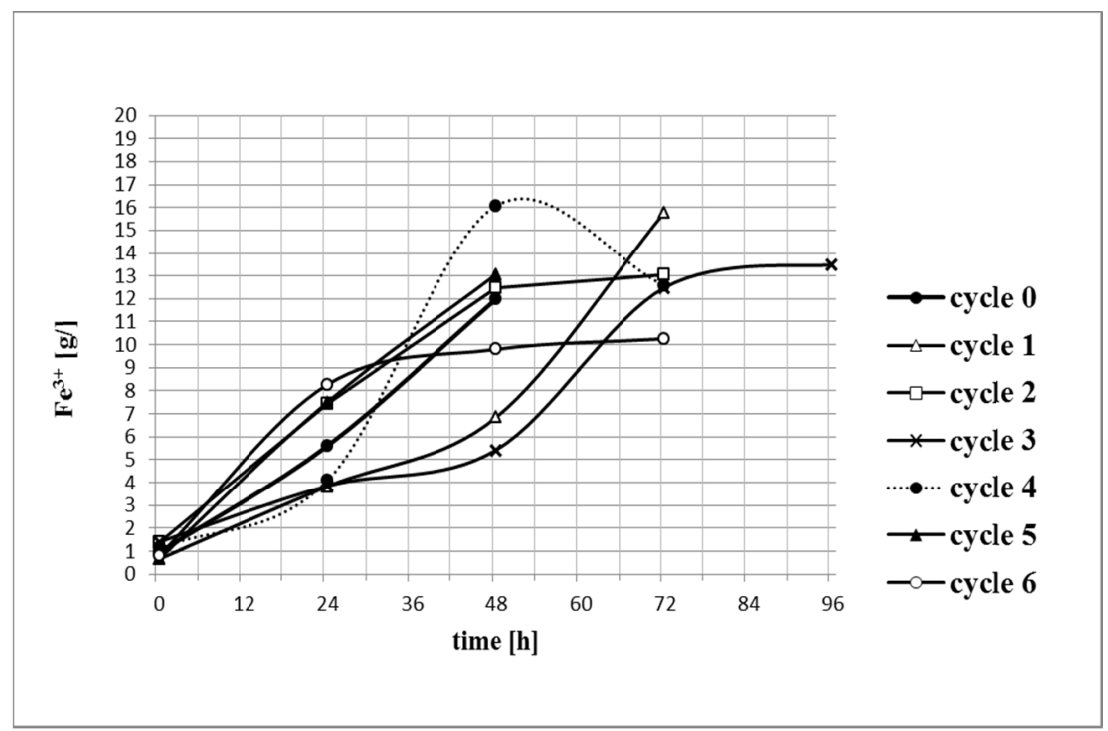

Fig. 5. Dynamics of ferric ions production in biofilm - biological control in $15 \mathrm{~K}$ medium (cycle 0 ), five cycles in $15 \mathrm{~K}$ medium with $5 \mathrm{~g} / \mathrm{C} \mathrm{Cu}^{2+}$ and cycle 6 after removal of $\mathrm{Cu}^{2+}$ from liquid medium. 


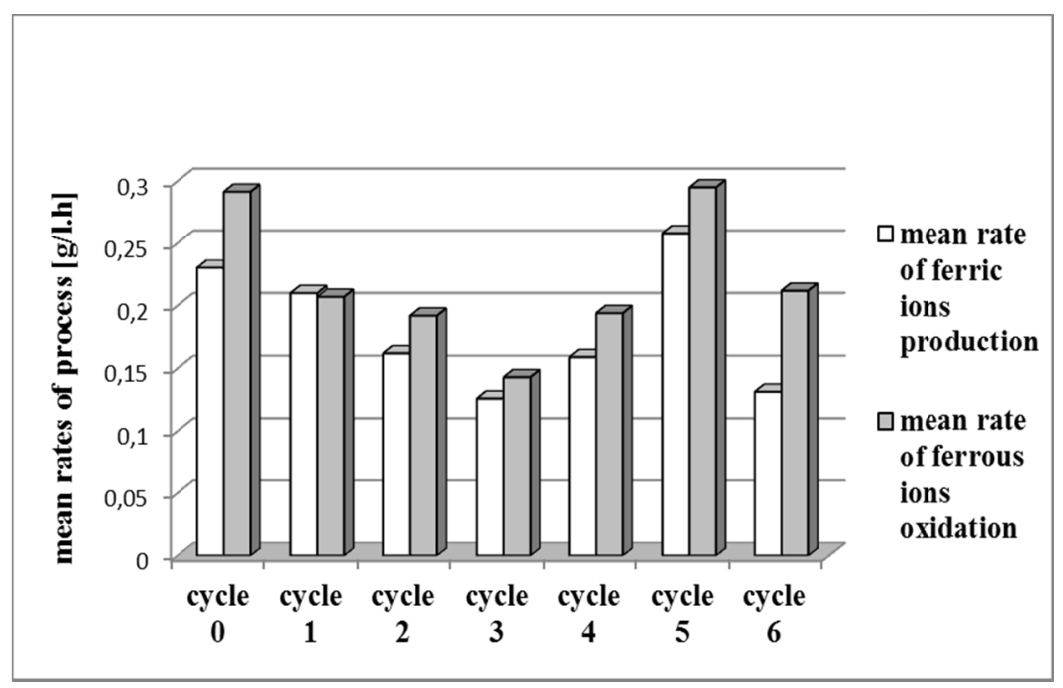

Fig. 6. Mean rates of ferric ions production in biofilm - biological control (cycle 0 ) in $15 \mathrm{~K}$ medium, five cycles in $15 \mathrm{~K}$ medium with $5 \mathrm{~g} / 1 \mathrm{Cu}^{2+}$ and cycle 6 after removal of $\mathrm{Cu}^{2+}$ from liquid medium.

It can be seen that after the addition of copper ions, the mean rates decrease during the first three cycles of biofilm cultivation, then increase and reach those before the addition of copper ions.

From the results obtained, it can be concluded that in the sequential cultivation of biofilm culture in medium $15 \mathrm{~K}$ with added $5 \mathrm{~g} / \mathrm{l}$ copper ions the biofilm is adapted to the created conditions. The statistical analysis of the mean rates shows that the rates in cycle 0 and cycle 5 are statistically the same, which cofirms the above conclusions.

\section{Cultivation of biofilm in liquid medium $18 K$}

The comparison between process dynamics over the seven cycles of biofilm cultivation in culture medium $18 \mathrm{~K}$ in the presence of $5 \mathrm{~g} / \mathrm{l}$ copper ions is given on fig. 7. Full oxidation of the ferrous ions is reached for 48-72 hours. It can be seen that the process is most quickly carried out in Cycle 0 before the addition of copper ions. For the next four cycles (from Cycle 1 to Cycle 4 inclusive), biofilm retains the same run time to complete ferrous ion oxidation for 72 hours. For Cycle 5 and Cycle 6 for 24 hours, the highest concentration of ferric ions in the liquid phase is reached.

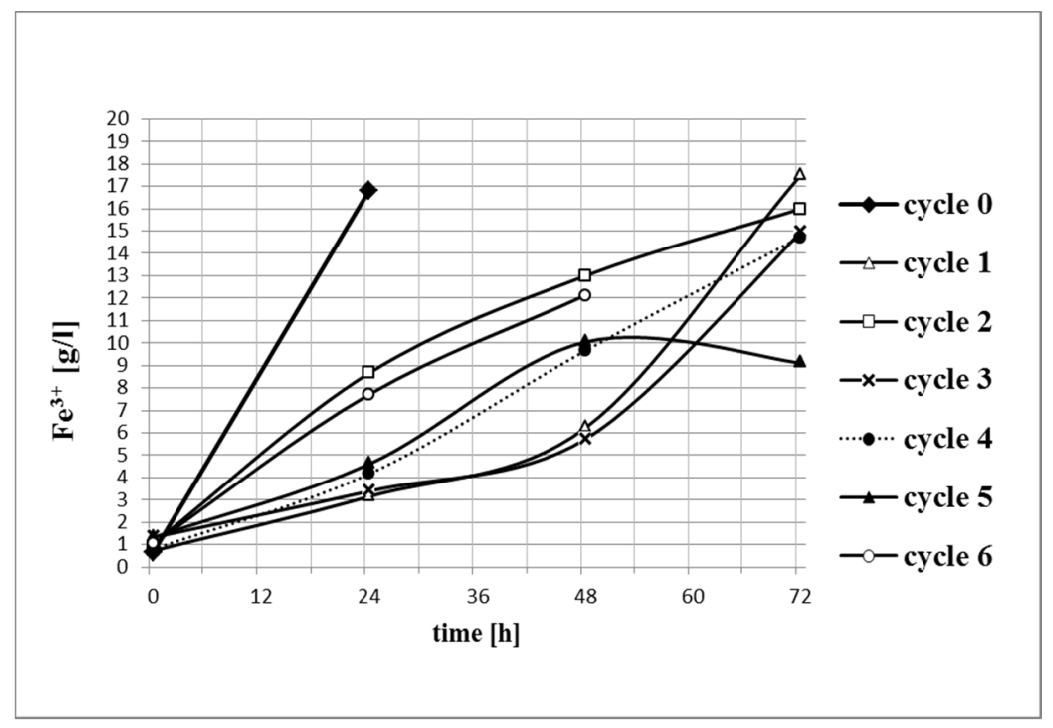

Fig. 7. Dynamics of ferric ions production in biofilm - biological control in $18 \mathrm{~K}$ medium (cycle 0 ), five cycles in $18 \mathrm{~K}$ medium with $5 \mathrm{~g} / \mathrm{C} \mathrm{Cu}^{2+}$ and cycle 6 after removal of $\mathrm{Cu}^{2+}$ from liquid medium. 
For each cycle of cultivation mean rates of ferrous ions oxidation and ferric ions production were calculated. The results are shown on Fig. 8. In consecutive cultivation of suspended cells in medium $18 \mathrm{~K}$ the mean rates are different for all cycles. In biofilm in medium $18 \mathrm{~K}$ after addition of copper ions there is decrease of mean rates compared to the first cycle, but they stay constant in the next cycles. Comparison of mean rates of ferrous ions oxidation shows that in biofilm they are higher than in suspended cultures.

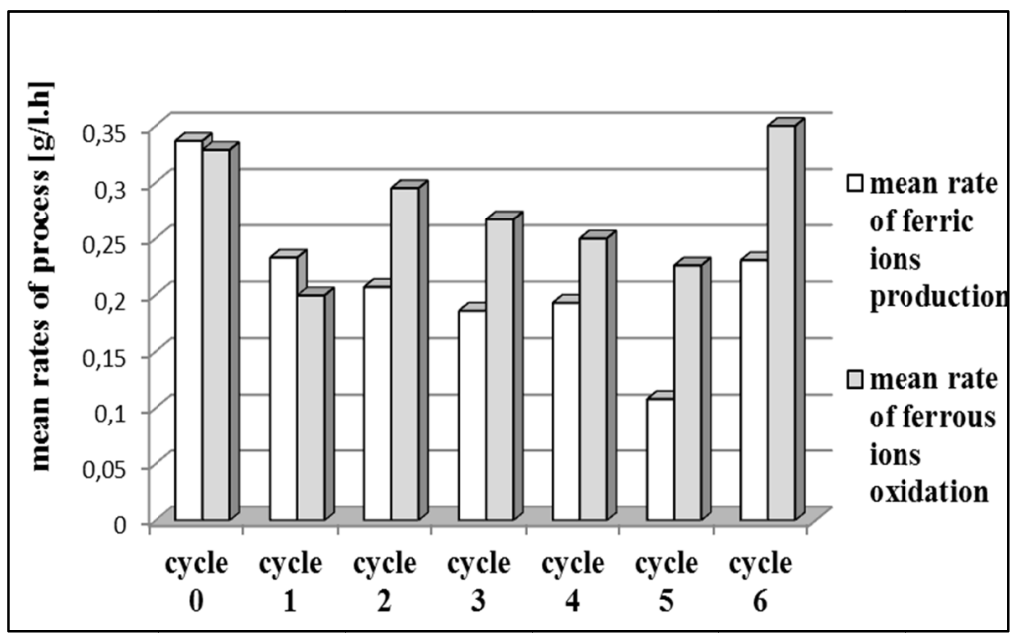

Fig. 8. Mean rates of ferric ions production in biofilm - biological control (cycle 0 ) in $18 \mathrm{~K}$ medium, five cycles in $18 \mathrm{~K}$ medium with $5 \mathrm{~g} / \mathrm{l} \mathrm{Cu}^{2+}$ and cycle 6 after removal of $\mathrm{Cu}^{2+}$ from liquid medium.

Comparison of the mean rates of the ferric ions oxidation process and the ferric ions production shows the following: after addition of the copper ions in $18 \mathrm{~K}$ culture medium, the rates decreases, through the next cycles from cycle 2 through cycle 4 it stays relatively close. The statistical analysis of all results shows that the rates are different, but the same rates are maintained during the first four cycles of copper ion treatment. The statistical analysis shows that during cycle 6 , after removal of the copper ions, the ferric ions production rate is the same as that of Cycle 1 through Cycle 4. These results show that the biofilm can function for four cycles in the presence of copper ions with a constant rate of ferric ions production.

\section{Determination of biofilm thickness}

After the end of biofilm cultivation it was determined thickness. Results are presented on Fig. 9. The highest thickness is biofilms grown in medium $15 \mathrm{~K}$ - about $380 \mu \mathrm{m}$. In medium $18 \mathrm{~K}$ the biofilm reaches 350 $\mu \mathrm{m}$. In 9K liquid medium the biofilm thickness is about $242 \mu \mathrm{m}$. A statistical processing is performed using thickness data on all media. In them the biofilm reaches a different thickness. To determine whether the differences are due to the different concentration of iron ions in the nutrient media, a statistical analysis of the biofilm thickness in each of the media was performed.

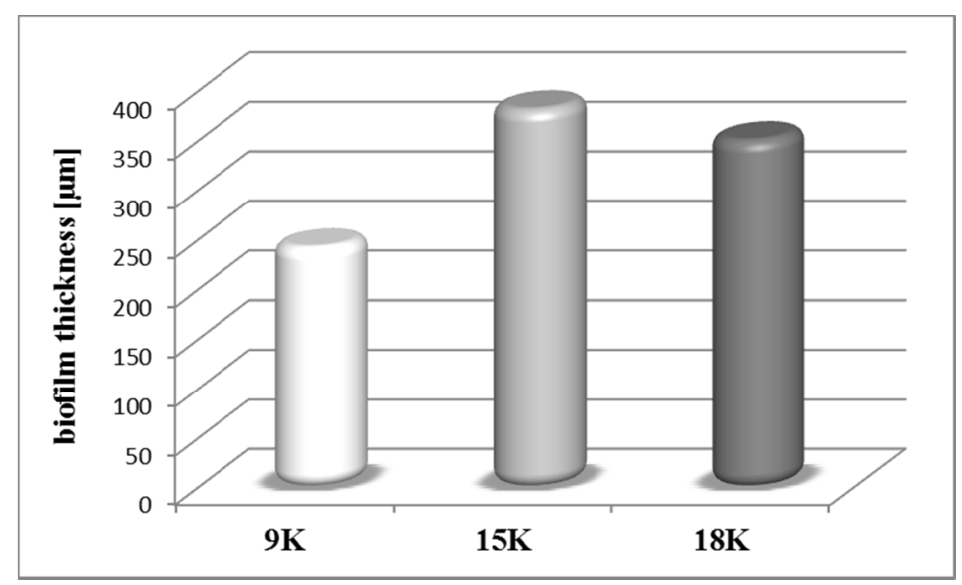

Fig. 9. Biofilm thickness after cultivation in $15 \mathrm{~K}$ and $18 \mathrm{~K}$ media with $5 \mathrm{~g} / 1 \mathrm{Cu}^{2+}$, biofilm thickness after cultivation in $9 \mathrm{~K}$ medium with $5 \mathrm{~g} / 1 \mathrm{Cu}^{2+}$ is biological control. 
When grown in medium $18 \mathrm{~K}$ on the different carriers the biofilm grows to the same thickness. In medium $15 \mathrm{~K}$, the thickness at the end of the experiments differs on the individual carriers. The uneven growth of biofilm and reaching statistically different thicknesses under the same conditions in a flask is due to the specificity of the hydrodynamic and mass-exchange characteristics of the shaker flasks with a biofilm carrier placed therein. The uneven growth of biofilm in the depth of the liquid phase was also observed in previous studies [20,21,22].

It was made a comparison of mean rates of ferrous ions production between the suspended cultures and the biofilm of Acidithiobacillus ferrooxidans JCM 3863. The results are presented on Fig. 10.

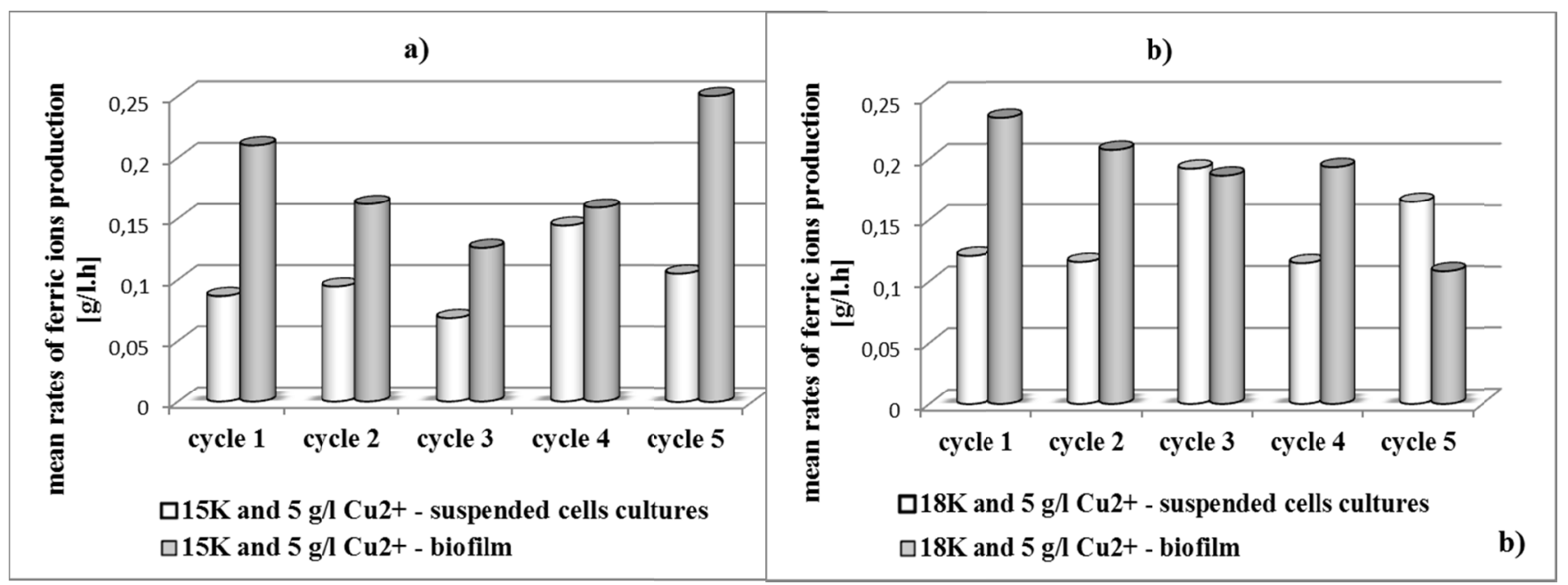

Fig. 10. Mean rates of ferrous ions oxidation -a) in medium $15 \mathrm{~K}$ with $5 \mathrm{~g} / 1 \mathrm{Cu}^{2+}$;

b) in medium $18 \mathrm{~K}$ with $5 \mathrm{~g} / 1 \mathrm{Cu}^{2+}$.

In all investigated initial iron ion concentrations, the mean rates of the process in biofilm is higher, in some cases this difference is 2-3 times. This differences are, in fact, greater because a part of the ferric ions are precipitated in form of jarosite in the flasks and biofilm. That kind of sedimentation is always observed in cultivation of Acidithiobacillus ferrooxidans in media with ferrous ions [19]. The basis for the dynamics of the process to be traced to the variation of the ferric ions concentration and on this basis to calculate the mean rates is that the possibility and the rate of leaching of metals from solid materials depends very much on the concentration of the ferric ions in the liquid phase.

\section{CONCLUSION}

From the comparison of the dynamics of ferric ions production in suspended cultures and biofilm can be concluded that the biofilm is more suitable for industrial biotechnological processes occurring in the presence of copper ions and high concentrations of iron ions.

\section{REFERENCES}

1. Cui J., Forssberg E. Mechanical recycling of waste electric and electronic equipment: A review. Journal of Hazardous Materials, 2003, 99 (3): 243-263.

2. Khalid A., Rhamdhani M.A., Brooks G., Masood S. Metal Extraction Processes for Electronic Waste and Existing Industrial Routes: A Review and Australian Perspective. Resources, 2014, (3): 152-179.

3. Ilyas S., Anwar M. A., Niazi S.B., Ghauri M.A., Bioleaching of metals from electronic scrap by moderately thermophilic acidophilic bacteria. Hydrometallurgy, 2007, 88: 180-188.

4. Free M. L., Hydrometallurgy: Fundamentals and Applications, Chapter 5: Metal Extraction. John Wiley \& Sons, 2013, pp.159-165.

5. Singh, U. Sh, Kapoor K., Microbial Biotechnology. Oxford Book Company, Jaipur, India, 2010, ISBN: 978-93-80179-24-7.

6. Gyurov P., Mamatarkova V., Karadjova I., Potentialities of Metals Bioleaching From Printed Circuit Boards by Acidithiobacillus ferrooxidans JCM 3863. Youth Science Conference Kliment's days, november 2015, Sofia, Bulgaria, 2015, Abstract Book p. 40. 
7. Ivanova E., Mamatarkova V., Karadjova I., Ecological application of Acidithiobacillus ferrooxidans JCM 3863 for biohydrometallurgical recovery of rare and precious metals from spent catalytic converters. Ecological Engineering and Environment Protection (EEEP'2015), Science Conference, Burgas, Bulgaria, 2015.

8. Mamatarkova V., Ivanova E., Karadjova I., Investigation of the possibility of using Acidithiobacillus ferrooxidans JCM 3863 for biohydrometallurgical recovery of rare and precious metals from spent catalytic converters, Annuaire de l'Université de Sofia "St. Kliment Ohridski”, Faculte De Biologie, 2014,100 (4): 63-69, First National Conference of Biotechnology, Sofia 2014.

9. Tzenov M., Mamatarkova V., Karadjova I. Bacterial oxidation of ferrous ions by biofilm of Acidithiobacillus ferrooxidans JCM 3863 in the presence of a mixture of $\mathrm{Ni}^{2+}, \mathrm{Co}^{2+}$ and $\mathrm{Cu}^{2+}$. Youth Science Conference Kliment's days, Sofia, Bulgaria, 2015, Abstract Book, p. 30.

10. Mamatarkova V., Karadjova I., Mitov G., Gerginova N., Geneva S., Influence of silver ions on oxidation activity of Acidithiobacillus ferrooxidans JCM 3863 in biofilm. International Conference "Bioscience - Development and New Opportunities", Sofia, Bulgaria, 2013, Abstract Book, p. 98.

11. Nikolov L., Valkova-Valchanova M., Mehochev D., Oxidation of High Ferrous Iron Concentrations By Chemolithotrophic Thiobacillus Ferrooxidans In Packed-Bed Bioreactors. Journal of Biotechnology, 1988, 7 (2): 87-94.

12. Karamanev D., Nikolov L., A comparison between the reaction-rates in biofilm reactors and free suspended cells bioreactors. Bioprocess Engineering, 1991, 6 (3): 127-130.

13. Karamanev D., Nikolov L.,"Influence of Some Physicochemical Parameters on Bacterial Activity of Biofilm: Ferrous Iron Oxidation by Thiobacillus ferrooxidans", "Biotechnology and Bioengineering",1988, vol. 31, pp. 295-299.

14. Silverman, M.P., Lundgren, D.G., A study on the chemoautotrophic iron bacterium Ferrobacillus ferrooxidans. I. An improved medium and a harvesting procedure for securing high cell yields. Journal of Bacteriology, 1959, 77: 642-647.

15. Nikolov L., Karamanev D., Mamatarkova V., Mehochev D., Dimitrov D., Properties of the biofilm of Thiobacillus ferrooxidans formed in rotating biological contactor, Biochemical Engineering Journal, 2002, 12 (1): 43-48.

16. Mamatarkova, V., Dynamics of bacterial oxidation of high concentrations of iron ions, doctoral dissertation, Sofia University "St. Kl. Ohridski ", Sofia, Bulgaria, 2002. (in Bulgarian)

17. Karamanev D., Nikolov L., Mamatarkova V. Rapid simultaneous quantitative determination of ferric and ferrous ions in drainage waters and similar solutions. Minerals Engineering, 2002, 15 (5): 341-346

18. Grishin S.I., Bigham J.M., Tuovinen O.H.. Characterization of Jarosite Formed upon Bacterial Oxidation of Ferrous Sulfate in a Packed-Bed Reactor. Applied and Environmental Microbiology, 1988, 54 (12): 3101-3106.

19. Nikolov L, V. Mamatarkova, Dynamics of sedimentation of trivalent iron ions in biodegradable reactor, Ecological engineering and environmental protection, 2005, vol. 1: 42-51. (in Bulgarian)

20. Mamatarkova V., Tsenov M. Dynamics of Acidithiobacillus ferrooxidans JCM 3863 biofilm formation on two different inert carriers, Days of Biomechanics 2014, Sofia, 2014, 20-21 November, Book of abstracts, p. 13. (in Bulgarian)

21. Mitov G., Investigation of the influence of silver ions and nanoparticles on the biofilm behavior of Acidithiobacillus ferrooxidans JCM 3863, Master thesis, Faculty of Biology, Sofia University "St. Kliment Ohridski ", Sofia, 2013 (in Bulgarian)

22. Tzenov, M., Influence of toxic metals ions on biological activity of Acidithiobacillus ferrooxidans biofilm JCM 3863, Diploma thesis, Faculty of Biology, Sofia University "St. Kliment Ohridski ", Sofia, 2013. Abstracts, p. 13 (in Bulgarian) 


\title{
КУЛТИВИРАНЕ НА СУСПЕНДИРАНИ КУЛТУРИ И БИОФИЛМ НА ACIDITHIOBACILLUS FERROOXIDANS JCM 3863 В ПРИСЬСТВИЕТО НА МЕДНИ ЙОНИ И ПРИ ВИСОКИ КОНЦЕНТРАЦИИ НА ЖЕЛЕЗНИ ЙОНИ
}

\author{
Кристина Лазарова, Вяра Маматаркова
}

Резюме: Бактериите Acidithiobacillus ferrooxidans ce прилагат в много биотехнологични процеси като биоизлугване на метали от нискокачествени руди и в някои процеси с екологично значение като пречистване на отпадни води и газове, отстраняване на метали от твърди отпадъци.

Суспендираните култури и биофилмът на Acidithiobacillus ferrooxidans JCM 3863 са култивирани в две среди - с 15 и 18 g/l начална концентрация на железни йони. Биофилмът и суспендираните култури са култивирани в пет последователни цикъла във всяка хранителна среда в присъствие на 5 g/l медни йони, до пълното окисление на железните йони. Накрая е измерена дебелината на биофилма.

Средните скорости на окисление бяха сравнени за всеки цикъл на култивиране. При последователно култивиране на суспендирани клетки и биофилм в среда $15 К$ след добавяне на медни йони средните скорости намаляват в първите три цикъла, след това се увеличават в цикли 4 и 5. При последователно култивиране на суспендирани клетки в среда $18 \mathrm{~K}$ средните стойности са различни за всички цикли . В биофилм в среда $18 \mathrm{~K}$ след добавяне на медни йони има намаляване на средните стойности в сравнение с първия цикъл, но те остават постоянни в следващите цикли. Сравнението на средните стойности на окисление на железни йони показва, че при биофилмите те са по-високи, отколкото при суспендираните култури.

В резултат на представеното изследване може да се направи заключение, че биофилмът е по-подходящ за промишлени биотехнологични процеси в присъствие на медни йони и високи концентрации на железни йони.

Ключови думи: Acidithiobacillus ferrooxidans, биофилм, медни йони, висока концентрация на железни йони

\section{Kristina Lazarova, PhD student}

Sofia University, Faculty of Biology

Department of Biotechnology

Sofia 1164, 8 Dragan Tzankov bld

Laboratory of Bioprocess systems

tel.: 028167310

e-mail: kristina.r.lazarova@gmail.com

\author{
Assoc. Prof. Vyara Mamatarkova \\ Sofia University, Faculty of Biology \\ Department of Biotechnology \\ Sofia 1164, 8 Dragan Tzankov bld \\ Laboratory of Bioprocess systems \\ tel.: 028167310 \\ e-mail: vsavamama@yahoo.com
}

